\title{
Unintended System Motion
}

National Cancer Institute

\section{Source}

National Cancer Institute. Unintended System Motion. NCI Thesaurus. Code C62813.

Problem associated with any motion of the system or components that was not initiated by the user. 